\title{
Curcuma Longa (Turmeric): A Condiment of Great Therapeutic Value Tested with the Ayurveda up to the Modern Medicine
}

\section{Shah NC*}

*Corresponding author: NC Shah, Founder \& Retired Director, Herbal Research \& Development Institute, U.P. (now Uttaranchal) \& Retired Senior-Scientist (CIMAP, CSIR), MS78, Sector-D, Aliganj, Lucknow-226024, India, Email: shahncdr@gmail.com

\section{Review Article}

Volume 5 Issue 1

Received Date: November 06, 2020

Published Date: January 06, 2021

DOI: $10.23880 /$ jonam-16000291

\section{Abstract}

Turmeric is associated and is a part of Indian's culture: it is an important ingredient in curry dishes; it is also used in many religious observances, as a cosmetic, a dye, and it enters in the composition of many traditional remedies. This paper deals with its botany, its earliest reference in 'Atharva Veda', its uses in folk medicine, folk cosmetics, as a folk condiment, folk dye, its folk-chemistry, used in folk culture, and etymology and philology of 36 Sanskrit names, its important chemical constituents and its pharmacodynamics, its biopiracy and finally, the conclusion and discussions with a suggestion that when drug or its therapeutic compounds have been pharmacologically and therapeutically tested then why it is not being used in the modern medicine as a post-operative drug.

Keywords: Curcuma longa; Folk-Cosmetics; Folk-Dyes; Ayurvedic

\section{Introduction with Aims}

Ethnologically turmeric occupies an important position in the life of the Indian people being the integral part of the cuisine, health, rituals, and religious ceremonies. It is being used from times immemorial in India not as culinary condiment but as well as a house hold medicine and cosmetics. It is also used in folk-medicine, folk-cosmetics, folk-dyes, etc. It has been used in Ayurvedic, Unani-Tibb, and Tibetan (Amchi) systems of medicine in India. It is also used in Chinese and Japanese systems of medicines.

The Main aim of this article is to review and discuss the origin \& botany, various vernacular names by which it is known in abroad and in India. The Sanskrit names have been mainly considered and have been deciphered etymologically and philologically. And, the result has revealed many interesting facts which were not known earlier. Further, its folk and domestic uses and its entry into Ayurvedic text books is discussed. Lastly, its chemical composition, pharmacodynamics, essential oil, cultivation, processing, biopiracy, and its export from the country have been dealt with.

\section{Material \& Methods}

The old and new literature on Curcuma longa has been studied and cited and many uses has been known personally and were cited.

\section{Observations and Results}

\section{Origin and Botany}

It is speculated that turmeric may have originated from South or South-East Asia, its centre of domestication is certainly the Indian subcontinent. Turmeric is botanically known as Curcuma longa L. syn. C.domestica Valen (Zingiberaceae). It is abot one-meter tall plant with large root-stock attached cylinders orange colour, the inside leaves are large, in tufts, oblong-lanceolate tapering to the 
base; flowers in spike10-15 cm long concealed by sheathing petiole, flowering bracts pale green. The rhizomes are 2.5$7 \mathrm{~cm}$ in length and about $2.5 \mathrm{~cm}$ in diameter.

\section{Its Vernacular Names in Different Languages}

$>$ Outside India: Arab- Aurkesafar. Kurkum, Urukesabhaghin, urukesabra,Ureka sufra, Zarsud, Persian-Darzardi; Dardachobah; Chinene-Jianghuang; Japanese-Ukon.

> In India: Bengali- Haldi, Pitras; English- Indian saffron, Turmeric,; Hindi- Haldi; Gujrati-Halada; MahrastraHalad; Kannad- Arsina; Punjabi- Haldar, Halja; TamilManjal; Telgu- Pampi, Pasupu

\section{Folk Medicinal Uses in India}

$>$ Oral: It is taken in common cold bronchitis and in intermittent fevers; flatulence, and stomach-ache indigestion and diarrhoea; hepatic disorder, and jaundice, in intermittent fevers it is usually taken with hot water. In painful affection due to sprains, swellings, cuts and wounds. After child delivery the women are usually given the body massage with turmeric powder mixed with mustard oil to relieve the inflammatory affections of joints, Turmeric is given with dried Ginger (Zingiber officinale) or 'Sonth', gum babool (Acacia nilotica), ajwain (Trachspermum ammi) and sugar or Gur (Jaggery) in powder form after delivery to strengthened the body muscles allaying pain. Doses: $2.5 \mathrm{mg} / \mathrm{kg}$ body weight (As suggested by the experts.)

$>$ Topical application: The paste is smeared on the head in vertigo, in body sprains, swellings, cuts, wounds, due to external injuries, etc.; skin infections, pimples, and foul ulcers; paste made in Gingelly (Sesamum indicum) oil (Til oil) is applied; the paste of turmeric in mixed with slaked lime and applied on external injuries.

$>$ Decoction: Decoction of the herb 1/20 and strained is used in purulent ophthalmia.

$>$ Fumes: The fumes of turmeric are inhaled in catarrh, coryza and hysterical fits.

> In house-hold remedies as a folk-medicine: It is used in household remedies for various purposes. In every house in India it is used as an condiment and also it is used in sprains, as a pain reliever for internal and external injuries,

$>$ As a folk cosmetic and folk dyes: The paste of turmeric powder with mustard oil or coconut oil is applied on face and body and left for some time, and then it is washed with water to get a natural shining glow of yellow colour. In Kumaon and other parts of the country, the powder was used as dye colour and for dyeing clothes and the ceremonial threads (Janeu).

$>$ As Folk condiment: In rural and tribal villages the rhizomes of turmeric are cut into pieces and dried and added to the boiling curry, which gives a turmeric flavour to the food and the pieces are also eaten along with the curry.

$>$ An Important part of Indian culture: It is a must that brides and bridegrooms are smeared with a paste of turmeric and then given a bath. The wealthier people mix sandal powder with the paste of turmeric. This tradition is met in every part of the country; Even the Muslims have adopted this culture. In Kumaon, turmeric is ground with the mustard seeds and the paste is added with mustard oil and smeared on the body of both bride and bridegroom. It is regarded as an auspicious and holy article throughout the country. In earlier days the writing of 'invitation letters' was not so common and in its place, the people use to send a piece of the rhizome to the friends and relatives denoting that they have been invited in a marriage ceremony or for other social functions. As the writing of letters began then it was customary to sprinkle the letter or the invitation card with a coloured solution of turmeric thus in some way retaining indirectly the old cultural tradition.

$>$ Folk-chemistry or 'Roli' known 'Pithyan' in Kumaon: In Kumaon and in other parts of the country an especial dye of red colour is called 'Roli'.or 'Pithiyan'. Is prepared from turmeric powder, which is applied on the forehead as a holy sign or mark with the thumb or middle finger, on religious ceremonies and social functions or occasions. The 'Roli' or 'Pithian' 'is prepared and the folk-chemistry is as under:

Kept in a Copper bowl

Turmeric rhizome + Lime juice + Suhaga Rhizome ------- $\rightarrow$ ' Roli' or 'Pithiyan'

(yellow colour) (Borax) for 5-6 days (red colour) of red colour

$>$ Chemistry: In presence of a mineral acid Curcumin + Boric acid--

Rosocayanin molecule and

Rubrocurcumin (Boroncurcumin chelates

The red colour is due to rosocayanin and rubrocurcumin, Tonnesen [1].

> Turmeric in Tantra Shastra: Turnmeric has been used in Tantra Shastra, Bhat (nd) [2]. It has been used as a substitute of the gem Yellow Saphire and for many other Tantrik uses.

$>$ Turmeric in Atharva Veda: According to Sharma [3], turmeric was mentioned in Atharvaveda, the first book on Ayurveda in which mono-herbal use of the herbs are mentioned. This book was written about 1000-1500 


\section{Journal of Natural \& Ayurvedic Medicine}

B.C. He claimed to identify the herb Turmeric as 'Haladi' and 'Haridrava' and as 'Anjan' and 'Harit' but the other Ayurvedic and Sanskrit experts do not agree with this and they did not give any reference of Turmeric in their texts. Even, Caraka and Sushurta's (ca 100 A.D.Caraka and Sushruta 200-500 A.D) have not mentioned the herb in their works. However, this study requires further detail and thorough investigation by the AyurvedicSanskrit scholars with Vedic knowledge whether the plant is mentioned in Atharva Veda or not.

- The Amarsimha Amarkosha [4] written in 400 A.D. is a repository of Sanskrit words or the synonymy of Sanskrit names of the plants, animals, deities, celestial bodies, etc. These names are based on the qualities, properties, distribution cultural and medicinal uses of plants. The synonyms used for turmeric are about 5 in number. However, Kirtikar \& Basu [5] has also given the Sanskrit synonyms of Turmeric 36 . These Sanskrit names have been deciphered etymologically and philologically to give an idea of the status of the plant in ancient times when it was used as a medicine, dye, cosmetics, its mode of application, distribution, etc. are described as under, Shah [6] (Table 1).

\begin{tabular}{|c|c|}
\hline $\begin{array}{l}\text { Sanskrit names as } \\
\text { synonyms }\end{array}$ & Etymology \& Philology \\
\hline \multicolumn{2}{|r|}{ As dyes \& cosmetics } \\
\hline 'Varna-Datri' & $\begin{array}{l}\text { Varna' means colour and “Datri' means one which imparts As it is used for dyeing and for body } \\
\text { complexion hence called, one which imparts colour }\end{array}$ \\
\hline Dirgha-ranga' & Dirgha' means lasting, 'ranga' is colour meaning the colour of which lasts for long \\
\hline 'Shobhna' & $\begin{array}{l}\text { Shobhna' means brilliant When it was used by the ladies on the face and body as a cosmetic and } \\
\text { the and the body used to glow and shine }\end{array}$ \\
\hline 'Pinja,'Pita,'Pitika' & All meaning yellow colour \\
\hline 'Ranjini' & Ranjini' means dyeing As it was used to dye clothes, body and face, therefore, called 'Ranjini' \\
\hline $\begin{array}{l}\text { Hemragi','Hemragini' } \\
\text { 'Kanchini' 'Swarna-varna' }\end{array}$ & $\begin{array}{c}\text { All denotes golden colour The colour obtained is golden colour or the rhizome is of golden } \\
\text { colour }\end{array}$ \\
\hline \multicolumn{2}{|r|}{ Mode of preparation and time of application: } \\
\hline 'Gharsini,',Kasada', 'Kaspa' & All words mean that the rhizome is ground on stone to make a paste before application \\
\hline 'Nisha”, 'Shyama', 'Yamini', & All words mean 'night' Possibly it was used in the night \\
\hline Varnagi' & $\begin{array}{c}\text { Var' means 'bridegroom and 'Angi' means to put on the bridegroom body was pasted with } \\
\text { turmeric pastebefore he leaves to the bridal house for marriage }\end{array}$ \\
\hline Taboos: & $\begin{array}{l}\text { This tradition still prevails. } \\
\end{array}$ \\
\hline 'Aneshtha' & $\begin{array}{l}\text { Means the thing which is not allowed to be offered in sacrificial fire or 'Homa'. It denotes that } \\
\text { turmeric is not offered as an oblation in 'Homa' }\end{array}$ \\
\hline \multicolumn{2}{|r|}{ Abstractive properties } \\
\hline 'Bhadra' & $\begin{array}{c}\text { Means auspicious or fortune giving. Possibly in earlier days it was used as an amulet or gem and } \\
\text { regarded as fortune giving }\end{array}$ \\
\hline 'Mangalprada,'Mangalia' & Both words mean 'welfare-bestower' \\
\hline 'Pavitra' & 'Pavitra' means holy. It is regarded as a holy article \\
\hline 'Subhagya' & It means 'good luck', which bestows good luck to the user who uses it as an amulet \\
\hline 'Yoshit-Priya', 'Yuvati' & $\begin{array}{c}\text { Yoshit' means young 'Priya' liked and loved. 'Yuvati' means young lady. It means it is liked and } \\
\text { loved by the young ladies }\end{array}$ \\
\hline “Hridya-Vilasani” & "Hridya' means heart and 'Vilasani' means that delights or charm. It charmed the ladies heartily \\
\hline \multicolumn{2}{|r|}{ After deities name } \\
\hline $\begin{array}{l}\text { 'Shiva', 'Uma,'Gauri', } \\
\text { 'Laximi' }\end{array}$ & The Hindu deities \\
\hline \multicolumn{2}{|r|}{ Medicinal properties } \\
\hline 'Haridra' & From two words, 'Harit', jaundice and 'Dravya' article \\
\hline 'Jwarantika & Jwar' means fever and 'Antika' is ending, which ends fever \\
\hline
\end{tabular}




\begin{tabular}{|c|c|}
\hline 'Krimighni' & Kirmi' means worms and 'Ghani' means destroyer. It destroys the intestinal worms or other \\
worms of the body
\end{tabular}

Table 1: Etymology and philology of Sanskrit names.

\begin{tabular}{|c|c|}
\hline Chemical composition & \% Dry weight \\
\hline Carbohydrate & 60 to $70 \%$ \\
\hline Protein & 6 to $9 \%$ \\
\hline Fat (ether sol) & $5.1 \%$ \\
\hline Mineral & $3.5 \%$ \\
\hline Fibre & 3 to $8 \%$ \\
\hline Vit. C & $49.8 \mathrm{mg} / 100 \mathrm{~g}$ \\
\hline Niacin & $4.8 \mathrm{mg} / 100 \mathrm{~g}$ \\
\hline Phosphorus & $0.286 \mathrm{mg} / 100 \mathrm{~g}$ \\
\hline Iron & $0.186 \mathrm{mg} / 100 \mathrm{~g}$ \\
\hline Vit.B2 & $0.19 \mathrm{mg} / 100 \mathrm{~g}$ \\
\hline Potassium & $0.025 \mathrm{mg} / 100 \mathrm{~g}$ \\
\hline Sodium & $0.01 \mathrm{mg} / 100 \mathrm{~g}$ \\
\hline Calcium & $0.146 \mathrm{mg} / 100 \mathrm{~g}$ \\
\hline Vit. B1 & $0.09 \mathrm{mg} / 100 \mathrm{~g}$ \\
\hline Vit. A as carotene & 50 I.U./100g \\
\hline Calories (As energy) & $349 / 100 \mathrm{~g}$ \\
\hline Curcumin (diferuloyl methane) & $2.5 \mathrm{mg} / 100 \mathrm{~g}$ \\
\hline Essential oil & 2 to $5.6 \%$ \\
\hline $\begin{array}{c}\text { Sesquiterpene ketone as } \\
\text { tumerones }\end{array}$ & $\begin{array}{l}58.0 \% \text { (In the essential } \\
\text { oil) }\end{array}$ \\
\hline Zingiberene & $25.0 \%$-do- \\
\hline Tertiary alcohol & $9.0 \%$-do- \\
\hline$\delta, \alpha-$ phellendrene & $1.0 \%$-do- \\
\hline Cineol & $1.0 \%$-do- \\
\hline$\delta$-Sabinene & $0.6 \%$-do- \\
\hline Borneol & $0.5 \%$-do- \\
\hline
\end{tabular}

Table 2: Chemical Composition.

There are a number of chemical constituents in turmeric rhizome; Duke [7] reported about 95 organic and inorganic compounds, however only the important ones are tabulated in Table 2.

Essential oil and Curcumin: We have seen the important constituents of essential oil in Table 2. It mainly composed of sesquiterpenes ketones known as turmerones, it also contains three major curcuminoids of which curcumin (diferuloylmethane) is the most significant. These curcuminoids are responsible for the yellow colour of the rhizome and also for a wide range of pharmacological and therapeutic activities. Curcumin is the most important constituent of turmeric rhizome. It is insoluble in water and soluble in alcohol and acetone. The quality of oleoresin is adjudged from the quantity of curcumin. Usually, it is $2-2.5 \%$.

$>$ The Pharmacodynamics: A good number of pharmacological and clinical trials and experiments have been conducted on turmeric, powder, curcumin, and essential oil and these have been reviewed from time to time, such as Tonnensen; Ammon \& Wahl, Tang \& Eisbrand [7-9] and many others. The important pharmacological and clinical works are tabulated in Table 3.

However, Srimal [36] in a detailed review also added few more pharmacological and therapeutic activities apart from above such as; anticancer, anti-proliferative on cancer cells, immuno-stimulant, in metabolic disorder (diabetes, etc) and its effect on the respiratory system. The companies Phytopharma working on medicinal plants have found that it is useful in bowel-cancer and about 17,000 people in States die of this disease (The Hindustan Times (Lucknow) 11 Jan 2001). Further, Editorial Team [37] reported a few more activities such as; in Malaria, HIV, and Alzheimer's diseases, etc. However, it has been found that no side effects or toxicity is observed. 
Journal of Natural \& Ayurvedic Medicine

\begin{tabular}{|c|c|}
\hline Activity & References \\
\hline Antibacterial & $\begin{array}{c}\text { Curcumin and essential oil - Ramprasad \& Sirsi [10]; Essential oil- Chopra, et al. } \\
\text { [11]; Rhizome powder-Lutomski, et al. [12] and Banerji \& Nigam [13] }\end{array}$ \\
\hline Anti-amoebic & Rhizome powder activity-against Entamoeba histolytica in vitro, Dhar, et al. [14] \\
\hline Anti-histaminic(anti-allergy) & Essential oil and powder, Chandra \& Gupta [15] \\
\hline Anti-inflammatory and anti-oedimic & $\begin{array}{c}\text { Rhizome powder and curcumin- Arora, et al. [16]; Srimal \& Dhawan [17]; Rhizome } \\
\text { powder-Yognarayan, et al. [18]; Curcumin-Ghatak \& Basu [19]; Essential oil- } \\
\text { Chandra \& Gupta [15] }\end{array}$ \\
\hline Antioxidative (Anti-oxidant) & Curcumin-Sharma, et al. [20], Toda, et al. [21] \\
\hline Anti-rheumatic & Curcumin-Deodhar, et al. [22] \\
\hline Anti-flatulent (Carminative) & Essential oil- Chopra, et al. [11]; Curcumin-Bhawani Shankar, et al. [23] \\
\hline Hypo-lipidemic (Blood sugar lowering) & Curcumin-Srinivasan [24] \\
\hline $\begin{array}{l}\text { Choleretic (Enhances the flow of bile } \\
\text { juice in the digestion of fat) }\end{array}$ & Powder and curcumin-Ramprasad \& Sirsi [10] Essential oil-Ozaki \& Liang [25] \\
\hline Cytotoxic & Powder-Matthes, et al. [26] \\
\hline Hepatoprotective & Powder-Hikino [27]; Curcumin-Kiso, et al. [28] \\
\hline $\begin{array}{l}\text { Hypochlorestemic (lowering down of } \\
\text { cholesterol of blood) }\end{array}$ & $\begin{array}{l}\text { Curcumin- Ramprasad \& Sirsi [29], Srinivasan, et al. [30], Rao, et al. [31], Hansel } \\
\text { [32] }\end{array}$ \\
\hline $\begin{array}{c}\text { Hypotensive (Lowering of blood } \\
\text { pressure) }\end{array}$ & Sodium curcuminate- Rao, et al. [33] \\
\hline Respiratory troubles & Powder-Jain, et al. [34] \\
\hline Wound Healing & Powder-Gujral, et al. [35] \\
\hline
\end{tabular}

Table 3: Activitys.

\section{Turmeric Cultivation, Processing \& Export}

$>$ Cultivation: India is the World's largest producer and exporter of turmeric. Other producers in Asia include Bangladesh, Pakistan, Sri Lanka, Taiwan, China, Burma (Myanmar), and Indonesia. Turmeric is also produced in the Caribbean and Latin America: Jamaica, Haiti, Costa Rica, Peru, and Brazil.

$>$ In India, it is cultivated commercially approximately in an area of 1.5 lakh hectares with an annual production of 6,59,000 tonnes. It is grown in the states of Andhra Pradesh, Maharashtra, Tamilnadu, Kerala and Orissa. Among the states, Andhra Pradesh is the leader in the production with around $55-57 \%$ share of the Country's production. It is cultivated in Guntur, Karimnagar, Nizamabad, Cuddapah, Warangal and parts of Godavari district. However, the best quality turmeric is produced from Tamilnadu.

$>$ Processing: Processing is the most important part of the business of turmeric trade. Under this, the freshly dig rhizomes are cleaned, cooked in $100^{\circ} \mathrm{C}$ and dried and then graded to select out the polishable rhizome pieces and polished by removing the outer layer and then coloured with turmeric powder and marketed. The process of polishing is dealt with in detail, Satyanarayan \& Sukumaran [38].

$>$ Export: India shares around $90 \%$ of the global turmeric production. However, out of the production in India, $90 \%$ is consumed locally and the rest is exported. India is today the largest exporter of turmeric to discerning countries like the Middle East, the UK, USA and Japan. Turmeric from India exported as a whole, in powder form and as oleoresin with rich curcumin contents and other inherent qualities. Indian turmeric is considered the best in the world.

$>$ Bio-piracy of Turmeric: In December 1994 two NRIs Dr S.K.Das and Harihar Kohli of the University of Mississipi had filed a patent no. 5401504 at the US Patent and Trade Mark Office for the invention which claimed," the use of turmeric at the site of injury by topical application and /or oral intake of turmeric will promote healing wounds." The patent was granted to them in March 1995. It was a real case of Intellectual Property Right (IPR) not against any individual but of the entire country (India) and also other third world or developing countries, who mostly depend on the herbs for their day to day ailments and diseases as a part of their traditional culture. Dr RA Mashelkar, then DG CSIR challenged this 
patent through a leading US patent attorney to fight up the case. A vast literature of the use of 'Haldi' in different languages from all parts of the country was collected and presented as documentary proof to claim that it's the Indian heritage. Unlike 'Neem' this time the case was won. This was a landmark victory not only for CSIR or India but for other developing countries too. In words of Dr Mashelkar, "this is a significant development of far-reaching consequences for the protection of the traditional knowledge base not only of India but with other third world countries", Shah [39] (Figures 1-6).

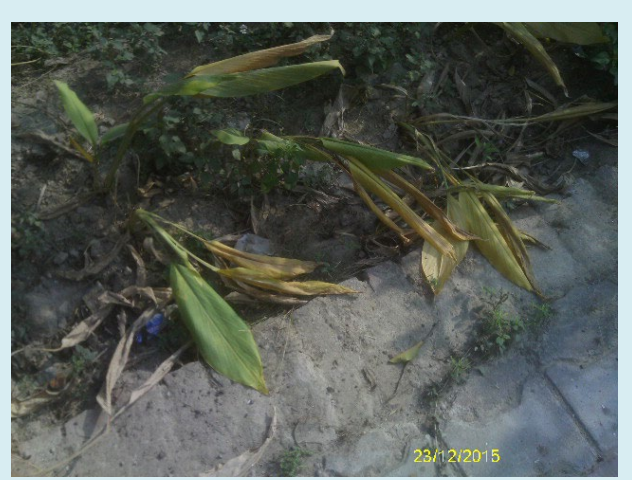

Figure 1: The Curcuma plants grown by the author.

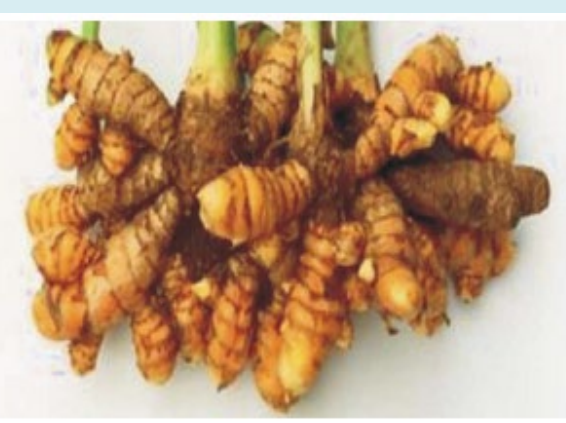

Figure 2: The rhizomes attached to the plants.

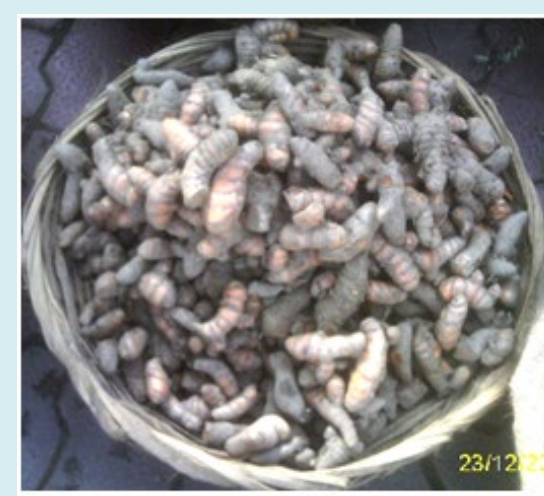

Figure 3: The rhizomes for the sale in the market of Lucknow.

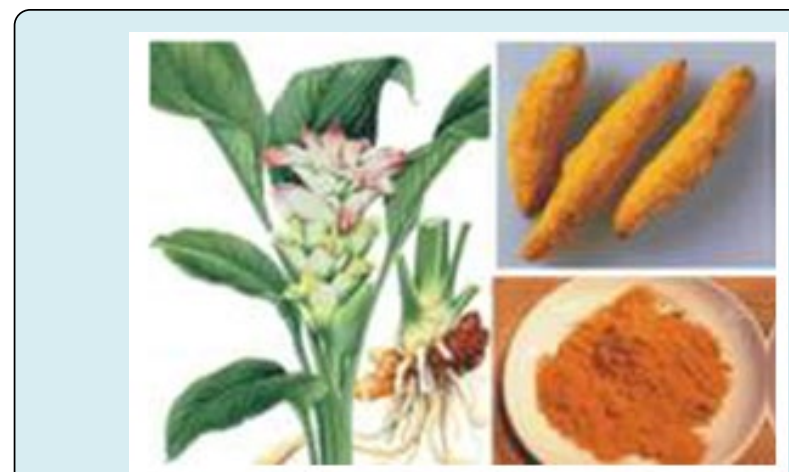

Figure 4: The plant the treated rhizome and the powder made.

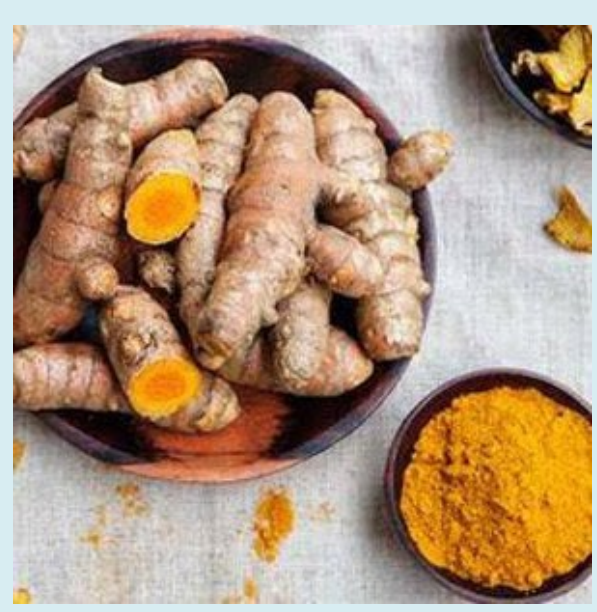

Figure 5: The untreated dry rhizomes and the powder made from it.

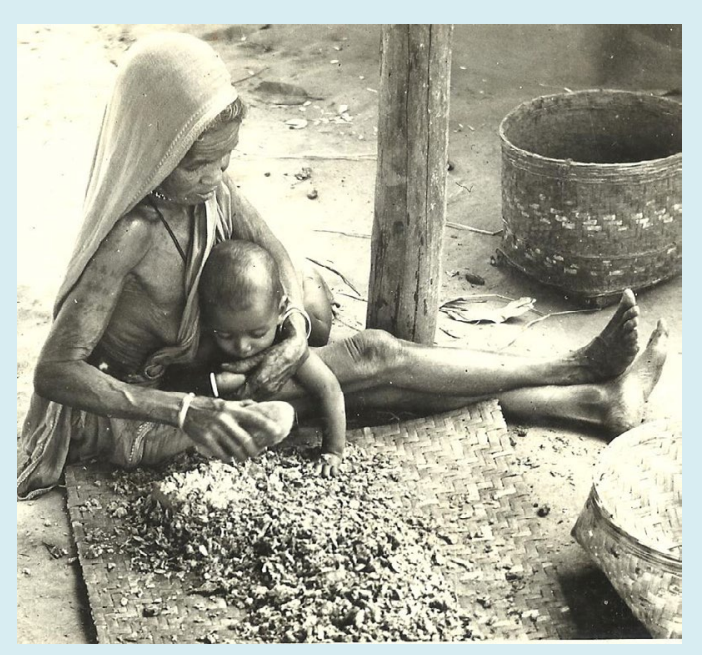

Figure 6: A tribal woman with her child sitting and breaking the dried rhizomes of Turmeric. They have little knowledge of its therapeutic uses but they use it as a culinary herb and cultivate it 


\section{Conclusion and Discussion}

The main Ayurvedic literatures, Atharva Veda, Caraka and Sushruta do not mention this plant. It is first time mentioned in Bhava Prakash Nighantu. Turmeric is well mentioned only with 5 names in the Sanskrit literature in Amarkosha written in 400A.D. From the above study, it is concluded that the turmeric's medicinal uses and the Sanskrit names as described after Bhava Prakash Nighanu, and in other Ayurvedic literatures is about 36 and which are deciphered etymologically and philologically. It has been tested pharmacologically and therapeutically as reviewed. Thus it provides a strong scientific footing for the use of turmeric in different ailments and diseases. The inclusion of the herb as a condiment not only gives us the cooked food with pleasing flavour and colour but also makes the food prophylactic against a number of diseases and ailments as indicated above. But in modern medicine, it is not being used and accepted through its powder, essential oil, and the main constituent curcumin have been found as a powerful antiinflammatory and anti oedemic agents. At least it should have been used in India in the post-operative treatments in place of synthetic anti-inflammatory and anti oedemic drugs, which are with severe side effects if taken for a long duration while turmeric and its compounds have no side effects yet reported. However, in the U.K. an extract of the herb is being developed into a veterinary arthritis drug, Yaniv, Zohra \& Uriel, Bachrach [40]. It is strange to note it has been not recorded in tribal medicine though it is used for culinary purpose in Maharastra, D. Souza [41-44].

\section{References}

1. Tonnesen HM (1986) Chemistry Stability and analysis of Curcumin-a Naturally Occurring Drug Molecule. Institute of the Pharmacy University of Oslo, Norway.

2. Prasad BD (nd) (1986) 'Chamatkari Vanaspati Tantra Shastra' Rojgar Prakashan, Mathura (U.P.), pp: 58-70.

3. Sharma DC (1969) Vedon mein dravyaguna shastra. Gujrat Ayurvedic University, Jamnagar.

4. Simha A (2001) Amarkosa (Namalinganusasana), Chaukhamba Sanskrit Sansthan, Varanasi, pp: 418.

5. Kirtikar KR, Basu BD (1933) Indian Medicinal Plants vol. IV. Lalit Mohan Basu, Allahabad.

6. Shah NC (1997a) Traditional uses of turmeric (Curcuma longa). India J Med \& Arom Pl Sci 19: 948-954.

7. Duke J (1992) Handbook of phytochemical constituents of GRAS herbs and other economic plants. CRC Press Inc Florida, pp: 654.

\section{Journal of Natural \& Ayurvedic Medicine}

8. Ammon HPT, Wahl MA (1991) Pharmacology of Curcuma longa. Planta Medica 57(1): 1-7.

9. Tang W, Eisenbrand G (1992) Chinese Drugs of Plant Origin.Curcuma ssp. Chapter 52. Springer Berlog Berlin, pp: 401-415.

10. Ramprasad C, Sirsi M (1956) J Sci Indus Res 15C: 262265.

11. Chopra RN, Chopra IC, Handa KL, Kapur LD (1958) Indigenous Drugs of India. UN Dhar \& Sons, Calcutta, pp: 325-634.

12. Kedzia LJ, Debslea BW (1974) Planta Med 26: 9-19.

13. Banerji A, Nigam SS (1978) Antimicrobial efficacy of the essential oil of Curcuma longa. Indian J Med Res 68: 864866.

14. Dhar ML, Dhar MM, Mehrotra BN, Nand B, Ray C (1986) Indian J Exp Biol 6: 232-247.

15. Chandra D, Gupta SS (1972) Anti-inflammatory and antiarthritic activity of volatile oil of Curcuma longa (Haldi). Indian J Med Res 60(1): 138-142.

16. Arora RB, Basu N, Kapoor V, Jain AP (1971) Antiinflammatory studies on Curcuma longa (turmeric). Indian J Med Res 59(8): 12891295.

17. Srimal RC, Dhawan BN (1985) In "Development of Unani Drugs from Herbal sources and the role of Elements in their Mechanism of Action" Arora RB (Ed.), Hamdard National Foundation, Monograph. New Delhi, pp: 131142.

18. Yognarayan R, Saraf AP, Balwani JH (1976) Comparison of anti-inflammatory activity of various extracts of Curcuma longa (Linn). Indian J Med Res 64(4): 601-608.

19. Ghatak N, Basu N (1972) Sodium curcuminate as an effective anti-inflammatory agent. Indian J Exp Biol 10(3): 235-236.

20. Sharma SC, Mukhtar M, Sharma SK, Murti KCR (1972) Lipid peroxide formation in experimental inflammation. Biochem Pharmacol 21(8): 1210-1214.

21. Toda S, Miyase T, Arichi H, Tanizawa H, Takino Y (1985) Natural antioxidants. III. Antioxidative components isolated from rhizome of Curcuma longa L. Chem Pharm Bull 33(4): 1725-1728.

22. Deodhar SD, Sethi R, Srimal RC (1980) Preliminary study on antirheumatic activity of curcumin (diferuloyl methane). Indian J Med Res 71: 631-6634. 
23. Shankar B, Sreenivas TN, Murthy V (1979) Indian J Exp Biol 17: 1363-1366.

24. Srinivasan M (1972) Effect of curcumin on blood sugar as seen in a diabetic subject. Indian J Med Sci 26(4): 269270.

25. Ozaki Y, Liang OB (1988) Cholagogic action of the essential oil obtained from curcuma xanthorrhiza ROXB. Shoyakugaku Zaashi 42(4): 257-263.

26. Matthes MWD, Luu B, Ourision G (1980) Cytotoxic components of Zingiber zerumbet, Curcuma zedoaria and C. domestica. Phytochem 19(12): 2643-2650.

27. Hikino H (1985) Yakuke Z Ashi 125: 109-118.

28. Kiso Y, Suzuki Walanbe N, Oshima Y, Hikini N (1983) Antihepatotoxic principles of Curcuma longa rhizomes. Planta Medica 49(3): 185-187.

29. Ramprasad C, Sirsi M (1957) Observations on the pharmacology of curcuma longa linn. Indian J Physiol Pharmacol 1(2): 136-143.

30. Srinivasan M, Aiyar AS, Kapur OP, Kokatnur MG, Rao DS, et al. (1964) Indian J Exp Biol 2: 104.

31. Rao SD, Satyanarayan CN, Srinivasan M (1970) J Nutrition 100: $1307-1315$.

32. Hansel IR (1985) Dent Apoth Zeit 125: 1373.

33. Rao TS, Basu N, Seth SD, Siddiqui HH (1984) Indian J Physiol Pharmacol 28: 2111.

34. Jain JP, Bhatnagar LS, Parsai MR (1979) J Res Indian Med
Yoga Homeo 14: 110.

35. Gujral ML, Chowdhary NK, Saxena PN (1953) The effect of certain indigenous remedies on the healing of wounds and ulcers. Indian Med Assoc 22(7): 273-276.

36. Srimal RC (1997) Turmeric: A brief review of medicinal properties. Fitoterapia 48(6): 483-493.

37. Editorial Team (2005) Herbal Tech Industry 2(1): 12-18.

38. Satyanarayan Ch.VK, Sukumaran CR (1999) On-Farm technology of turmeric processing and suggestions for mechanisation. The Andhra Agric J 46(3\&4): 229-233.

39. Shah NC (1997b) Biopiracy of therapeutic Haldi. The Hindustan Times (Lucknow) 27 $7^{\text {th }}$ Oct, pp: 12.

40. Zohra Y, Uriel B (2005) Handbook of Medicinal Plants. The Haworth Medical Press Inc. New York, pp: 156-157.

41. Marie D (1993) Tribal Medicine. Soc. for Promotion of Wastelands Develpoment, New Delhi-1, pp: 1-371.

42. Santapau H, Henry AN (1973) A Dictionary of the Flowering plants in India. Pub \& Info Directorate CSIR, New Delhi.

43. Shah NC (1994) An ethnobotanical study of turmeric, Curcuma longa L in the Indian Himalayas and other parts of the country. (Abstract) In Ethnobiology in Human Welfare Abstracts Fourth International Congress of Ethnobiology 17-21 November 1994, NBRI, Lucknow, pp: 314.

44. Takeda C (1971) Atlas of Medicinal Plants Pub. Takeda Chemical Industries Ltd. Osaka, Japan. 